\title{
Contrasting Water Use, Stomatal Regulation, Embolism Resistance, and Drought Responses of Two Co-Occurring Mangroves
}

\author{
Guo-Feng Jiang ${ }^{1, *(1)}$, Timothy J. Brodribb ${ }^{2}$, Adam B. Roddy ${ }^{3}$, Jin-Yan Lei ${ }^{1}$, Huai-Tong Si ${ }^{1}$, Pratima Pahadi ${ }^{4}$, \\ Yong-Jiang Zhang ${ }^{4}(\mathrm{D})$ and Kun-Fang Cao ${ }^{1}(\mathbb{D}$ \\ 1 Guangxi Key Laboratory of Forest Ecology and Conservation, State Key Laboratory for Conservation and \\ Utilization of Subtropical Agro-Bioresources, College of Forestry, Guangxi University, Daxuedonglu 100, \\ Nanning 530004, China; 18709681693@163.com (J.-Y.L.); sihuaitong2020@163.com (H.-T.S.); \\ kunfangcao@gxu.edu.cn (K.-F.C.) \\ 2 School of Biology, University of Tasmania, Hobart 7001, Australia; timothy.brodribb@utas.edu.au \\ 3 Department of Biological Sciences, Institute of Environment, Florida International University, Miami, \\ FL 33199, USA; aroddy@fiu.edu \\ 4 School of Biology and Ecology, University of Maine, Orono, ME 04469, USA; \\ pratima.pahadi@maine.edu (P.P.); yongiiang.zhang@maine.edu (Y.-J.Z.) \\ * Correspondence: gfjiang@gxu.edu.cn
}

check for updates

Citation: Jiang, G.-F.; Brodribb, T.J.; Roddy, A.B.; Lei, J.-Y.; Si, H.-T.; Pahadi, P.; Zhang, Y.-J.; Cao, K.-F. Contrasting Water Use, Stomatal Regulation, Embolism Resistance, and Drought Responses of Two Co-Occurring Mangroves. Water 2021, 13, 1945. https://doi.org/10.3390/ w13141945

Academic Editor: Luis Gimeno

Received: 15 June 2021

Accepted: 13 July 2021

Published: 15 July 2021

Publisher's Note: MDPI stays neutral with regard to jurisdictional claims in published maps and institutional affiliations.

Copyright: (c) 2021 by the authors. Licensee MDPI, Basel, Switzerland. This article is an open access article distributed under the terms and conditions of the Creative Commons Attribution (CC BY) license (https:// creativecommons.org/licenses/by/ $4.0 /)$.

\begin{abstract}
The physiological mechanisms underlying drought responses are poorly documented in mangroves, which experience nearly constant exposure to saline water. We measured gas exchange, foliar abscisic acid (ABA) concentration, and vulnerability to embolism in a soil water-withholding experiment of two co-occurring mangroves, Avicennia marina (Forsskål) Vierhapper (Verbenaceae) and Bruguiera gymnorrhiza (L.) Savigny (Rhizophoraceae). A. marina showed higher photosynthesis and transpiration than B. gymnorrhiza under well-watered conditions. Cavitation resistance differed significantly between species, with $50 \%$ cavitation occurring at a water potential $\left(\mathrm{P}_{50}\right)$ of $-8.30 \mathrm{MPa}$ for A. marina and $-2.83 \mathrm{MPa}$ for B. gymnorrhiza. This large difference in cavitation resistance was associated with differences in stomatal closure and leaf wilting. The rapid stomatal closure of B. gymnorrhiza was correlated with ABA accumulation as water potential declined. Meanwhile, stomatal closure and declining water potentials in A. marina were not associated with ABA accumulation. The safety margins, calculated as the difference between stomatal closure and embolism spread, differed between these two species (1.59 MPa for A. marina vs. 0.52 MPa for B. gymnorrhiza). Therefore, $A$. marina adopts a drought tolerance strategy with high cavitation resistance, while B. gymnorrhiza uses a drought avoidance-like strategy with ABA-related sensitive stomatal control to protect its vulnerable xylem.
\end{abstract}

Keywords: ABA; cavitation resistance; drought tolerance; hydraulic safety margin; stomatal regulation; gas exchange; salt management strategy

\section{Introduction}

Forests globally are experiencing high incidences of mortality due to increases in drought frequency and severity leading to plant hydraulic failure [1-6]. Maintaining a balance between the supply of liquid water and the loss of water vapor through transpiration is an essential challenge for plants. Under nonstressful conditions, the maximum fluxes of water moving into and out of the plant are controlled by the coordination between xylem and stomatal traits across vascular plant species [7-12], including in mangroves [13,14]. Under water deficits, limiting water loss helps to ensure that water potentials do not cause catastrophic hydraulic failure in the xylem water transport system. Declining water potentials can cause the formation of embolism in the xylem that prevents water flow, which is thought to be irreversible in most species [15-17]. Cavitation resistance is typically 
quantified as the water potential that induces a $50 \%$ decline in hydraulic conductivity $\left(\mathrm{P}_{50}\right)$, which correlates with drought-induced mortality across species in both natural [18] and experimental conditions [19]. Therefore, $\mathrm{P}_{50}$ is frequently considered to be a key functional trait related to plant drought tolerance $[4,18,20,21]$ and is associated with plant distributions [17,22-27]. The associations among water supply, water loss, and embolism resistance in mangroves are relatively poorly understood.

One way of limiting water loss during soil water depletion is to close stomata, which limits transpirational water loss and also $\mathrm{CO}_{2}$ uptake [28-30]. Active stomatal regulation associated with the phytohormone abscisic acid (ABA) in angiosperms and gymnosperms can preempt water potential declines that might otherwise lead to hydraulic failure [8,31,32]. Thus, hormonal regulation of stomatal conductance curtails water loss over both short and long timescales, but the sensitivities of stomata to ABA and of stomatal conductance to water potentials are variable among species [33-35]. How early and rapidly stomata close before incipient xylem cavitation also varies considerably among species, with some species closing their stomata rapidly to maintain high water potentials, while others close their stomata slowly as water potentials decline [36]. One way of quantifying the coordination between liquid- and vapor-phase water transport while water potentials decline is by calculating safety margins between critical thresholds of stomatal closure and xylem vulnerability to embolism spread. Safety margins vary among species and characterize drought strategies [4,37-42], but those of mangroves are relatively less studied [43].

While these physiological thresholds and safety margins have been characterized primarily for inland, terrestrial plants, mangroves represent an interesting comparison as they are terrestrial but constantly inundated with water. However, this water is saline and has water potentials as low as $-2.5 \mathrm{MPa}$, which is below the water potentials that would damage some terrestrial species [44-46], requiring that mangroves tolerate or avoid cavitation damage to their xylem network. Vulnerability to cavitation has been reported for only six true mangrove species, showing large interspecific variability $[13,43,44,47,48]$, and hydraulic safety margins of mangroves have not been well quantified. The saline environment has shaped the physiological strategies of mangroves [45,49-51], suggesting that they may have different safety margins than other inland plants. Mangrove plants usually extract water by maintaining extremely low xylem water potentials and conserve water by restricting water loss through unique structural and physiological adaptations $[45,49,50,52-55]$. Similar to other terrestrial plants, stomatal conductance in mangroves is limited by air humidity, soil nutrients, salinity, and water deficits in the dry season [56-59]. In addition, mangroves are known to exhibit unusually low ABA levels in reproductive structures, associated with vivipary, but higher levels of ABA in their leaves [60]. This atypical distribution of $\mathrm{ABA}$ questions whether mangroves use $\mathrm{ABA}$ to induce stomatal closure similar to inland angiosperms. Understanding these physiological thresholds of mangroves and the mechanisms by which they regulate water loss is becoming increasingly urgent, as mangroves are currently facing numerous threats, including sea-level rise $[61,62]$ and large-scale mortality due to extended drought $[63,64]$.

Here we characterized the stomatal regulation and vulnerability to xylem cavitation in response to drought for two mangrove species. Avicennia marina and Bruguiera gymnorrhiza, which commonly co-occur across the Indo-West Pacific area, but have different salt management strategies. A. marina has greater salinity tolerance and foliar salt glands and can be found in areas with extreme environmental conditions (e.g., the Red Sea, southern Australia, and New Zealand) and throughout intertidal regions. B. gymnorrhiza, in contrast, is moderately tolerant of saline conditions, lacks foliar salt glands, excludes salts, and shares most of its distribution with A. marina but is absent from extremely saline and dry areas and from low intertidal zones [45,49-51,65-69]. We measured gas exchange, water potential, foliar ABA concentration, and vulnerability to embolism spread to test whether the divergent salt management strategies and salt tolerances of these two species are associated with differences in hydraulic safety margins and physiological responses to drought. We hypothesized that: (1) the greater salt tolerance of $A$. marina would allow 
it to be more drought tolerant and maintain physiological function as water potentials decline; (2) in contrast, B. gymnorrhiza, a salt excluder with lower salt tolerance, would use mechanisms like sensitive stomatal control and leaf wilting to avoid low water potentials and have lower tolerances to declining water potentials; (3) with greater drought tolerance, A. marina would have a larger hydraulic safety margin than B. gymnorrhiza.

\section{Materials and Methods}

\subsection{Plant Species and Study Site}

Seedlings of Avicennia marina were collected from Komi, Iriomote, Japan $\left(24^{\circ} 19^{\prime} \mathrm{N}\right.$ $123^{\circ} 54^{\prime} \mathrm{E}$ ), and of Bruguiera gymnorrhiza were collected from the Qinglangang Mangrove Nature Reserve at Wenchang, hainan, China $\left(19^{\circ} 37^{\prime} \mathrm{N} 110^{\circ} 50^{\prime} \mathrm{E}\right)$, and transported to the campus of guangxi University, Nanning (Guangxi, China, $22^{\circ} 50^{\prime} \mathrm{N} 108^{\circ} 17^{\prime} \mathrm{E}$ ). They were then grown in square pots measuring $7.5 \mathrm{~cm}$ on a side $\times 30 \mathrm{~cm}$ tall, filled with commercial organic fermented soil substrate (waste from fungus culture, grass ash, humus, and perlite; hongfang Livestock Technology, Nanning, guangxi, China) in a glasshouse with natural lighting, a night-day temperature range of $15-35^{\circ} \mathrm{C}$, and $60-90 \%$ air humidity throughout the year. Prior to initiating the drought experiment of the 2-year-old seedlings, the potted seedlings were kept partially submerged in buckets filled with water and salt $(\mathrm{NaCl}, 0.6 \% \mathrm{~g} / \mathrm{v}$ in water), with water added weekly to maintain the water level. To initiate the drought experiment, potted seedlings were removed from the buckets to dry, with no water or salt being added throughout the duration of the experiment.

\subsection{Vulnerability to Cavitation Using the Optical Method}

Vulnerability to cavitation was quantified using the optical method (OV curve) $[70,71]$. The vulnerability was quantified on the main stems of 2-year-old seedlings of each species ( $\mathrm{n}=7$ for $B$. gymnorrhiza and $\mathrm{n}=8$ for $A$. marina). The stems were $3-6 \mathrm{~mm}$ in diameter and $60-90 \mathrm{~cm}$ in length. In addition to measurements on common garden seedlings, branches of mature trees of each species were also assessed for their vulnerability to embolism spread. These branches were collected from guangxi Beilun Estuary National Mangrove Reserve [13]. Five shoots from the adult trees of each species, each $2 \mathrm{~m}$ long and approximately $8 \mathrm{~mm}$ in diameter were cut between 20:00 and 20:30, placed in wet plastic bags for transporting to the lab, and the vulnerability was assessed early the next day. Three of these shoots per species were measured.

All stems were imaged using an 8-megapixel camera with a $20 \times$ lens and attached to the stem using a custom clamp and connected to a Raspberry Pi capturing images every five minutes according to the instructions at http://www.opensourceov.org (accessed on 20 August 2018). A small area of the bark about $20-30 \mathrm{~mm}$ in length was carefully removed from one side of the stem, where a thin layer of hydrogel (Tensive gel; Parker) was applied. Stems were allowed to dehydrate slowly on the bench, and images were captured until no more changes were observed in the stem reflectance, which lasted about $135 \mathrm{~h}$ for both species. At the same time, a stem psychrometer (model PSY1; ICT, Australia) was installed about $20 \mathrm{~cm}$ proximal to the region being imaged on each stem. Water potential was recorded every $10 \mathrm{~min}$, while the cooling time for the psychrometer was checked periodically to ensure accurate measurement of the wet-bulb temperature. Periodic measurements of leaf water potential were made using a Scholander pressure chamber (resolution: 0.001 MPa; PMS Instrument Company, Albany, OR, USA) for comparison to measurements using the stem psychrometer. Water potential data measured by the pressure chamber were used for the OV curves when water potential was not monitored by the psychrometer. All image sequences were analyzed using Fiji according to the instructions at http: / / www.opensourceov.org (accessed on 20 August 2018) [72].

\subsection{Soil Water-Withholding Experiment}

Drought was imposed on 2-year-old potted seedlings of B. gymnorrhiza $(\mathrm{n}=3)$ and A. marina $(\mathrm{n}=5)$ by withholding water. A preliminary experiment indicated that $A$. marina 
may not exhibit an ABA response, and so we sampled this species more intensively. Three individuals of each species were maintained as controls with the watering and salt addition unchanged from pretreatment conditions. Throughout the experiment, we monitored the salinity status with an Em50 data logger and $\mathrm{ECH}_{2} \mathrm{O}$ GS3 that measures volumetric water content (VWC) and electrical conductivity (EC) of the soil. Where mature trees of both species are growing at the guangxi Beilun Estuary National Mangrove Reserve, the EC of the soil, a metric of salinity, was $11.11 \pm 1.11 \mathrm{mS} / \mathrm{cm}$, and the EC of seawater is generally $50 \mathrm{mS} / \mathrm{cm}$ at $25^{\circ} \mathrm{C}$. During the drought experiment, the EC of the droughted soil for A. marina was always less than $0.49 \mathrm{mS} / \mathrm{cm}$, while the EC of the control pots ranged from 0.27 to $1.6 \mathrm{mS} / \mathrm{cm}$ (Figure S1), suggesting that droughted seedlings did not suffer from osmotic stress, consistent with our visualization of an absence of visible symptoms of osmotic stress. The decline in EC among the droughted pots suggests that as the VWC declined, dissolved salts may have crystallized out of solution such that the soil water was becoming less saline despite a drier condition.

During the drought treatment, we measured stomatal conductance $\left(g_{s}\right)$ and leaf water potentials (LWP) at midday (between 11:00-13:00 h) two to three times per week. All measurements were made under ambient $\mathrm{CO}_{2}$ concentrations, and the photosynthetic photon flux density was held at $1500 \mu \mathrm{mol} \mathrm{m} \mathrm{m}^{-2} \mathrm{~s}^{-1}$. The light was generated by a 6400-02B LED Light Source (LI-6400; LI-COR Biosciences, Lincoln, NE, USA). Foliar ABA was extracted from the treatment, and control leaves only after $g_{s}$ of the treatment leaves had begun to decline. Gas exchange was measured on a single leaf of each plant under the glasshouse conditions (15-35 ${ }^{\circ} \mathrm{C}$ and $60-90 \%$ air humidity) using a portable infrared gas analyzer (LI-6400; LI-COR Biosciences, Lincoln, NE, USA). During instantaneous gas exchange measurements, leaf temperature control was set to $25{ }^{\circ} \mathrm{C}$ when the air temperature was below $20^{\circ} \mathrm{C}$, and, as a result, leaf temperature was never below $20^{\circ} \mathrm{C}$. The same leaf on each plant was measured for gas exchange throughout the experiment. At the time gas exchange measurements were made, a nearby leaf on the same plant was excised, enclosed in a humid plastic bag, stored in a cooler, and transported back to the laboratory, where water potential was measured within $2 \mathrm{~h}$ using a Scholander pressure chamber. For $A$. $m a-$ rina, the drought experiment lasted about five months (October 2017-March 2018) until the entire plant wilted. In contrast, the seedlings of B. gymnorrhiza were severely wilted after 20 days, at which time the experiment was stopped. The mean monthly air temperatures during the drought experiment were $23.3^{\circ} \mathrm{C}, 18.4{ }^{\circ} \mathrm{C}, 14.1{ }^{\circ} \mathrm{C}, 13.2^{\circ} \mathrm{C}, 14.1{ }^{\circ} \mathrm{C}, 19.8^{\circ} \mathrm{C}$, respectively (data were downloaded from http:/ / data.cma.cn, accessed on 10 July 2021).

\subsection{Foliar ABA Quantification}

One leaf per plant was excised, quickly plunged in liquid nitrogen, and kept frozen until transport back to the lab. Foliar ABA was extracted following previous protocols [73,74] with some modifications. Once in the lab, leaf fresh mass was determined to the nearest $0.1 \mathrm{~g}$, and the leaves were then ground using a Retsch shaker (MM400, Retsch, gmbH, germany). The ground powder was extracted twice with $1 \mathrm{~mL}$ of a 15:4 v/v solution of methanol-water. Formic acid was added to adjust the buffer $\mathrm{pH}$ to 5.5. The supernatant was concentrated to $50 \mu \mathrm{L}$ in an Eppendorf vacuum centrifuge (Eppendorf 5301 Vacufuge Speedvac Vacuum) at $30{ }^{\circ} \mathrm{C}$, and ethyl acetate $(500 \mu \mathrm{L})$ was added to extract the ABA. The ethyl acetate supernatant was concentrated into powder with an Eppendorf vacuum centrifuge at $30^{\circ} \mathrm{C}$, then the concentrated ABA powder was dissolved in pure methanol, and the sample purified through a syringe filter of pore size $0.22 \mu \mathrm{m}$.

Analyses of ABA concentration were performed using an in-line ultra-performance liquid chromatography tandem mass spectrometer (UPLC-MS, Agilent 1290 Infinity LC+6460 Triple Quadrupole LC/MS) system equipped with an ESI ion source, in multiple reaction monitoring (MRM) and positive/negative mode, with the capillary voltage set to $4 \mathrm{kV}$ of ESI+ and $3 \mathrm{kV}$ of ESI-, respectively. Solvents used were $0.1 \%$ formic acid $(v / v)$ in water (A) and methanol (B), and a flow rate of $0.3 \mathrm{~mL} / \mathrm{min}$ was used. A gradient was set as: $0-5 \mathrm{~min}$ 5-30\% B, 5-9 min 30-35\% B, 9-10 min 35-50\% B, 10-10.7 min 50-100\% B, 10.7-15 min 100\% 
B. Water symmetry C 18 column temperature was $25^{\circ} \mathrm{C}$, and injection volume was $1 \mu \mathrm{L}$. The MS source was operated with $\mathrm{N}_{2}$ (LCMS quality) at a $10 \mathrm{~L} \mathrm{~min}^{-1}$ gas flow, desolvation temperature, $360{ }^{\circ} \mathrm{C}$; source temperature, $300{ }^{\circ} \mathrm{C}$; and the pressure was $280 \mathrm{kPa}$. ABA concentration was calculated according to the standard curve, which was generated using the following standard concentrations: 1000, 100, 50, 20, 10, and $1 \mathrm{mg} / \mathrm{mL}$, all of which were prepared by dilution of intermediate standard solutions with the standard solvent.

\subsection{Data Analysis}

All statistical analyses were conducted using R software (version 3.4.4, R Development Core Team, Vienna, Austria). To determine differences between species in the VPD response of $g_{s}$, we used a linear mixed-effects model that included an interaction between species and VPD and a random effect of the individual plant, as implemented in the package "Ime4" [75].

To determine the sensitivity of $g_{s}$ to leaf water potential (LWP), we normalized each $g_{s}$ measurement to the maximum $g_{s}$ measured on that individual and fitted with nonlinear curves of the following form:

$$
100 * g_{s}=\frac{100}{\left(1+e^{\left(a\left(-\mathrm{P}-\mathrm{P}_{\mathrm{g} 50}\right)\right)}\right)}
$$

where $P_{\text {g50 }}$ is the water potential at which $g_{s}$ is $50 \%$ of maximum. From these fitted curves, the water potentials at $12 \%\left(\mathrm{P}_{\mathrm{g} 12}\right)$ and $88 \%\left(\mathrm{P}_{\mathrm{g} 88}\right)$ of maximum $g_{s}$ were also calculated. To calculate the sensitivity of $g_{s}$ to LWP, we calculated the slope between the fitted $g_{s}$ values and LWP within $0.3 \mathrm{MPa}$ of the $\mathrm{P}_{\mathrm{g} 50}$ value for each species. To determine the relationship between ABA and LWP and between ABA and $g_{s}$, we used linear models with an interactive effect of the individual for each species separately because we had no a priori expectations about the shapes of the response curves beyond linearity.

Vulnerability to embolism was assessed using the "fitplc" package to calculate critical water potential thresholds for each stem sampled for vulnerability [76]. In addition to the water potential at $50 \%$ embolism $\left(\mathrm{P}_{50}\right)$, we also calculated the water potentials at $12 \%$ embolism $\left(\mathrm{P}_{12}\right)$ and $88 \%$ embolism $\left(\mathrm{P}_{88}\right)$. Differences in vulnerability were assessed using ANOVA with an interaction between species and age (adult vs. seedling) for each of the three critical threshold values.

\section{Results}

\subsection{Photosynthetic Gas Exchange Traits}

Under well-watered conditions, $A$. marina had a significantly higher stomatal conductance $\left(g_{s}\right)$, photosynthetic rate $(A)$, and transpirational rate $(\operatorname{Tr})$ than $B$. gymnorrhiza (Table 1). No difference was detected between these two species in intercellular $\mathrm{CO}_{2} \mathrm{~mol}$ fraction and intrinsic water use efficiency $\left(A / g_{s} ;\right.$ Table 1$)$.

Table 1. Leaf photosynthetic gas exchange traits of the two mangrove species, measured before the initiation of the drought experiment and on individuals not used in the drought experiment. $A$, net $\mathrm{CO}_{2}$ assimilation rate at $1500 \mu \mathrm{mol} \mathrm{m}{ }^{-2} \mathrm{~s}^{-1}$ quantum; $g_{s}$, stomatal conductance; $C_{\mathrm{i}}$, intercellular $\mathrm{CO}_{2}$ mol fraction; $A / g_{s}$, intrinsic photosynthetic WUE, and $T_{\mathrm{r}}$, transpiration. Values are means $\pm \mathrm{SDs}(\mathrm{n}=5)$. Asterisks indicate statistically significant differences between the two species: ${ }^{*} p<0.05$ and ${ }^{* *} p<0.01$.

\begin{tabular}{|c|c|c|c|c|c|}
\hline Species & $A^{* *}\left(\mu \mathrm{mol} \mathrm{m}{ }^{-2} \mathrm{~s}^{-1}\right)$ & $g_{s}^{* *}\left(\mathrm{~mol} \mathrm{~m}^{-2} \mathrm{~s}^{-1}\right)$ & $C_{\mathrm{i}}(\mu \mathrm{mol} \mathrm{mol}-1)$ & $A / g_{s}(\mu \mathrm{mol} \mathrm{mol}-1)$ & $T_{\mathrm{r}} *\left(\mu \mathrm{mol} \mathrm{m} \mathrm{m}^{-2} \mathrm{~s}^{-1}\right)$ \\
\hline $\begin{array}{c}\text { Avicennia } \\
\text { marina }\end{array}$ & $13.43 \pm 2.61$ & $0.21 \pm 0.03$ & $296.3 \pm 16.1$ & $63.2 \pm 9.7$ & $4.26 \pm 0.53$ \\
\hline Bruguiera gymnorrhiza & $8.25 \pm 1.52$ & $0.15 \pm 0.01$ & $317.7 \pm 17.7$ & $56.3 \pm 12.7$ & $3.28 \pm 0.27$ \\
\hline
\end{tabular}




\subsection{Vulnerability to Embolism Formation and Spread}

Embolism in the stem xylem was visually observable in both species as stems dehydrated (Figure 1). Typically, the initial cavitation events occurred after dehydration of at least one day, during which the water potential was $-2 \mathrm{MPa}$ for B. gymnorrhiza and $-4 \mathrm{MPa}$ for $A$. marina. The cumulative embolized vessel area increased following a sigmoidal curve (Figure $1 \mathrm{~A}, \mathrm{C}$ ). Mean $\mathrm{P}_{50}$ values significantly differed between species $(\mathrm{F}=150.54, \mathrm{df}=1, p<0.001)$, while age classes $(p=0.49)$ did not, but there was a significant interaction between species and age class $(\mathrm{F}=8.03, \mathrm{df}=1, p<0.05)$. A. marina adults had a $\mathrm{P}_{50}$ of $-8.30 \pm 0.17 \mathrm{MPa}$, while B. gymnorrhiza adults had a $\mathrm{P}_{50}$ of $-2.83 \pm 0.10 \mathrm{MPa}$. A. marina seedlings had a $\mathrm{P}_{50}$ of $-7.55 \pm 0.29 \mathrm{MPa}$, and B. gymnorrhiza seedlings had a $\mathrm{P}_{50}$ of $-4.13 \pm 0.33 \mathrm{MPa}$ (Figure 1A,C; Table 2). Tukey post-hoc HSD tests revealed that all pairwise comparisons of $P_{50}$ values were significant (Bonferroni-corrected $\alpha=0.0083$ ) except for the intraspecific differences between adults and seedlings. For the $\mathrm{P}_{12}$, there was a significant effect of species $(\mathrm{F}=25.31, \mathrm{df}=1, p<0.001)$, but not for age class $(p=0.48)$, nor was there the interaction of species and age $(p=0.18)$. For the $\mathrm{P}_{88}$, there was a significant effect of species $(\mathrm{F}=139.39, \mathrm{df}=1, p<0.001)$ and the interaction between species and age class $(\mathrm{F}=6.14, \mathrm{df}=1, p=0.02)$, but not for age class alone $(p=0.81)$.
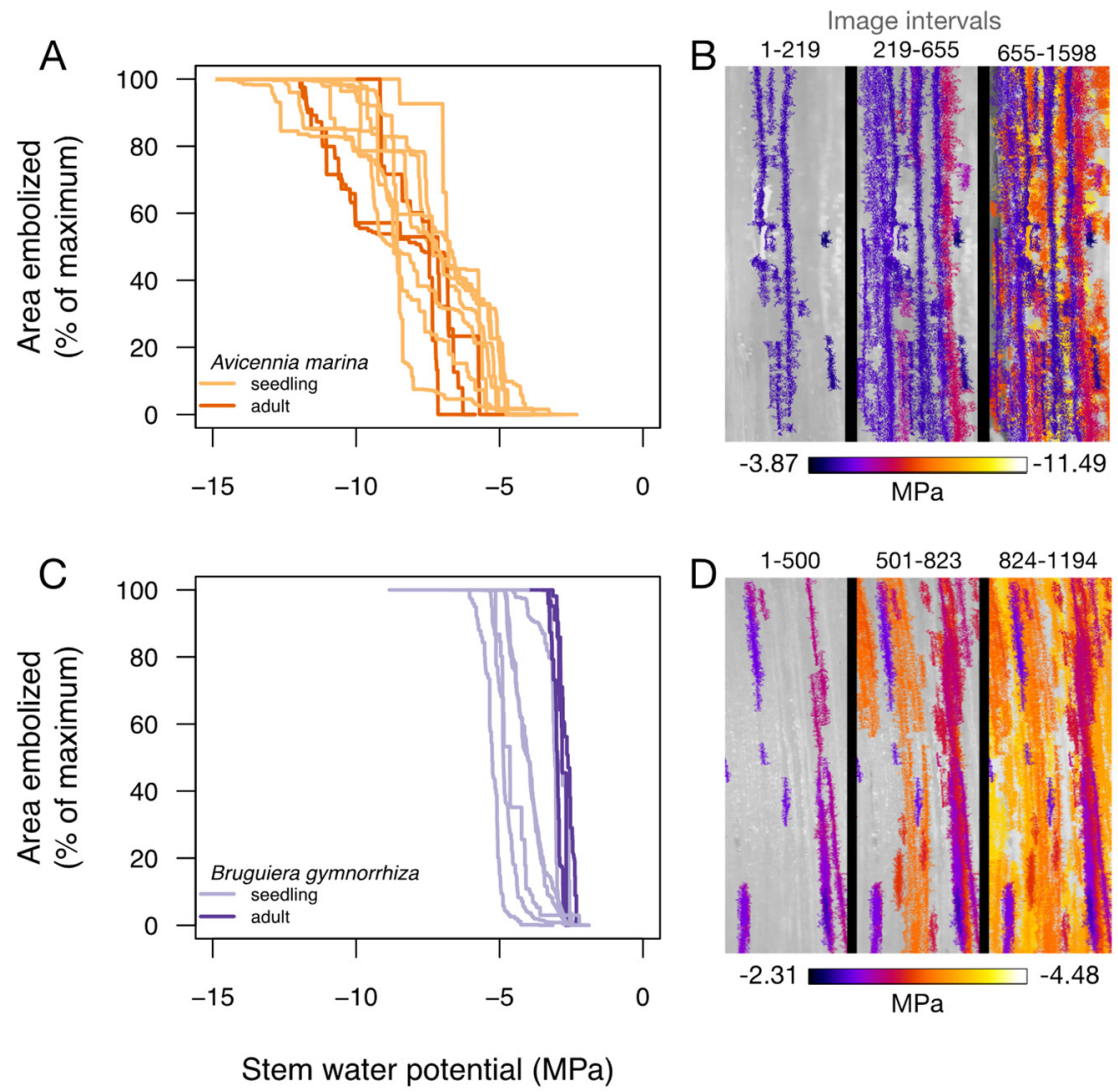

Figure 1. The cumulative area of cavitated xylem expressed as a function of stem water potential (vulnerability curves) of Avicennia marina (A) and Bruguiera gymnorrhiza (C). Mature tree stems from the field site $(\mathrm{n}=3)$ and seedlings ( $\mathrm{n}=8$ for $A$. marina, $\mathrm{n}=7$ for $B$. gymnorrhiza) from the greenhouse. (B,D) Color maps showing the spatial progression of cavitation with declining water potential of two representative individuals shown in $(\mathbf{A}, \mathbf{C})$. 
Table 2. Hydraulic traits variation of the two mangrove species.

\begin{tabular}{|c|c|c|c|}
\hline Trait* & Avicennia marina & Bruguiera gymnorrhiza & $t$-Test \\
\hline $\mathrm{P}_{88 \_ \text {seedlings }}(\mathrm{MPa})$ & $-9.56 \pm 0.46$ & $-4.53 \pm 0.35$ & $p<0.0001$ \\
\hline $\mathrm{P}_{88 \_}$mature (MPa) & $-10.75 \pm 0.90$ & $-3.02 \pm 0.07$ & $p<0.0001$ \\
\hline $\mathrm{P}_{50 \_ \text {seedlings }(\mathrm{MPa})}$ & $-7.55 \pm 0.29$ & $-4.13 \pm 0.33$ & $p<0.0001$ \\
\hline $\mathrm{P}_{50 \_}$mature $(\mathrm{MPa})$ & $-8.30 \pm 0.17$ & $-2.83 \pm 0.10$ & $p<0.0001$ \\
\hline $\mathrm{P}_{12 \_ \text {seedlings }(\mathrm{MPa})}$ & $-5.39 \pm 0.44$ & $-3.60 \pm 0.32$ & $p<0.0001$ \\
\hline $\mathrm{P}_{12 \_}$mature $(\mathrm{MPa})$ & $-5.71 \pm 0.48$ & $-2.56 \pm 0.15$ & $p<0.0001$ \\
\hline $\mathrm{P}_{\mathrm{g} 12 \_ \text {seedlings }}(\mathrm{MPa})$ & -3.80 & -3.08 & NA \\
\hline $\mathrm{P}_{\mathrm{g} 50 \_ \text {seedlings }(\mathrm{MPa})}$ & -2.63 & -2.70 & NA \\
\hline $\mathrm{P}_{\mathrm{g} 88 \text { _seedlings }(\mathrm{MPa})}$ & -1.47 & -2.33 & NA \\
\hline
\end{tabular}

${ }^{*}$ Note: $\mathrm{P}_{88} / \mathrm{P}_{50} / \mathrm{P}_{12}:$ water potential associated with $88 \%, 50 \%$, and $12 \%$ of cumulative embolism. $\mathrm{P}_{\text {g88 }} / \mathrm{P}_{\text {g50 }} /$ $\mathrm{P}_{\mathrm{g} 12}$ : water potential associated with $88 \%, 50 \%$, and $12 \%$ of maximum stomatal conductance.

\subsection{Response of Leaf Water Potential, $g_{s}$, and $A B A$ to an Experimental Drought}

The two species differed in their physiological responses to drought (Figure 2). Seedlings of A. marina lasted about 150 days before stomatal closure and leaf wilting, while $B$. gymnorrhiza lasted only about 20 days. Leaf water potentials (LWP) declined much more slowly in A. marina than in B. gymnorrhiza, with the minimum LWP of A. marina being about $-5 \mathrm{MPa}$ and the minimum LWP of $B$. gymnorrhiza being only $-3 \mathrm{MPa}$ (Figure 2A,F). Additionally, stomatal conductance and ABA were more variable during drought in $A$. marina than in B. gymnorrhiza. Some of this greater variation in A. marina was due to large variation among individuals, driven primarily by the death of one individual (denoted by inverted triangles in Figures 2 and 3) plant before the end of the experiment. This individual plant exhibited the lowest water potential and highest ABA concentrations (Figure 2D) on the last day of sampling before death. In contrast to A. marina, $g_{s}$ and LWP in B. gymnorrhiza declined consistently with less variation among individuals (Figure 2F,J).

The relationships between LWP, $g_{s}$, and ABA concentration differed between the two species (Figure 3 and Figure S2). In both species, declining LWP was associated with stomatal closure, but the sensitivity of $g_{s}$ to LWP was different between species. Although $g_{s}$ of $A$. marina began to decline at a higher water potential $\left(\mathrm{P}_{\mathrm{g} 88}=-1.47 \mathrm{MPa}\right)$ than B. gymnorrhiza $(-2.33 \mathrm{MPa})$, stomatal closure $\left(\mathrm{P}_{\mathrm{g} 12}\right)$ of B. gymnorrhiza occurred at a higher water potential $\left(\mathrm{P}_{\mathrm{g} 12}=-3.08 \mathrm{MPa}\right)$ than A. marina $\left(\mathrm{P}_{\mathrm{g} 12}=-3.80 \mathrm{MPa}\right)$. However, there was little difference between species in the water potentials at half of maximum stomatal closure (A. marina: $\mathrm{P}_{\mathrm{g} 50}=-2.63 \mathrm{MPa}$; B. gymnorrhiza: $\mathrm{P}_{\mathrm{g} 50}=-2.70 \mathrm{MPa}$ ). Based on the slope of the fitted curve at the $P_{550}, B$. gymnorrhiza was more than twice as sensitive as A. marina to LWP; for a $1 \mathrm{MPa}$ change in LWP, $g_{s}$ changed $116 \%$ for $B$. gymnorrhiza versus $42 \%$ for $A$. marina (Figure 3A,D). Relationships of LWP and $g_{s}$ with foliar ABA concentration also differed between the species. B. gymnorrhiza exhibited a linear increase in foliar ABA with declining LWP $\left(\mathrm{df}=13, \mathrm{R}^{2}=0.84, p<0.001\right.$; Figure $\left.3 \mathrm{E}\right)$, and $g_{s}$ declined linearly with increasing foliar ABA concentration $\left(\mathrm{df}=13, \mathrm{R}^{2}=0.58, p<0.001\right.$; Figure $\left.3 \mathrm{~F}\right)$. In contrast, $A$. marina exhibited no such clear patterns (Figure $3 \mathrm{~B}, \mathrm{C}$ ). Over a range of LWP similar to those measured in B. gymnorrhiza, A. marina exhibited no consistent increase in foliar ABA with declining LWP (Figure 3B). Similarly, there was no relationship between $g_{s}$ and ABA in A. marina (Figure 3C), despite its foliar ABA concentrations being as low as in B. gymnorrhiza. 

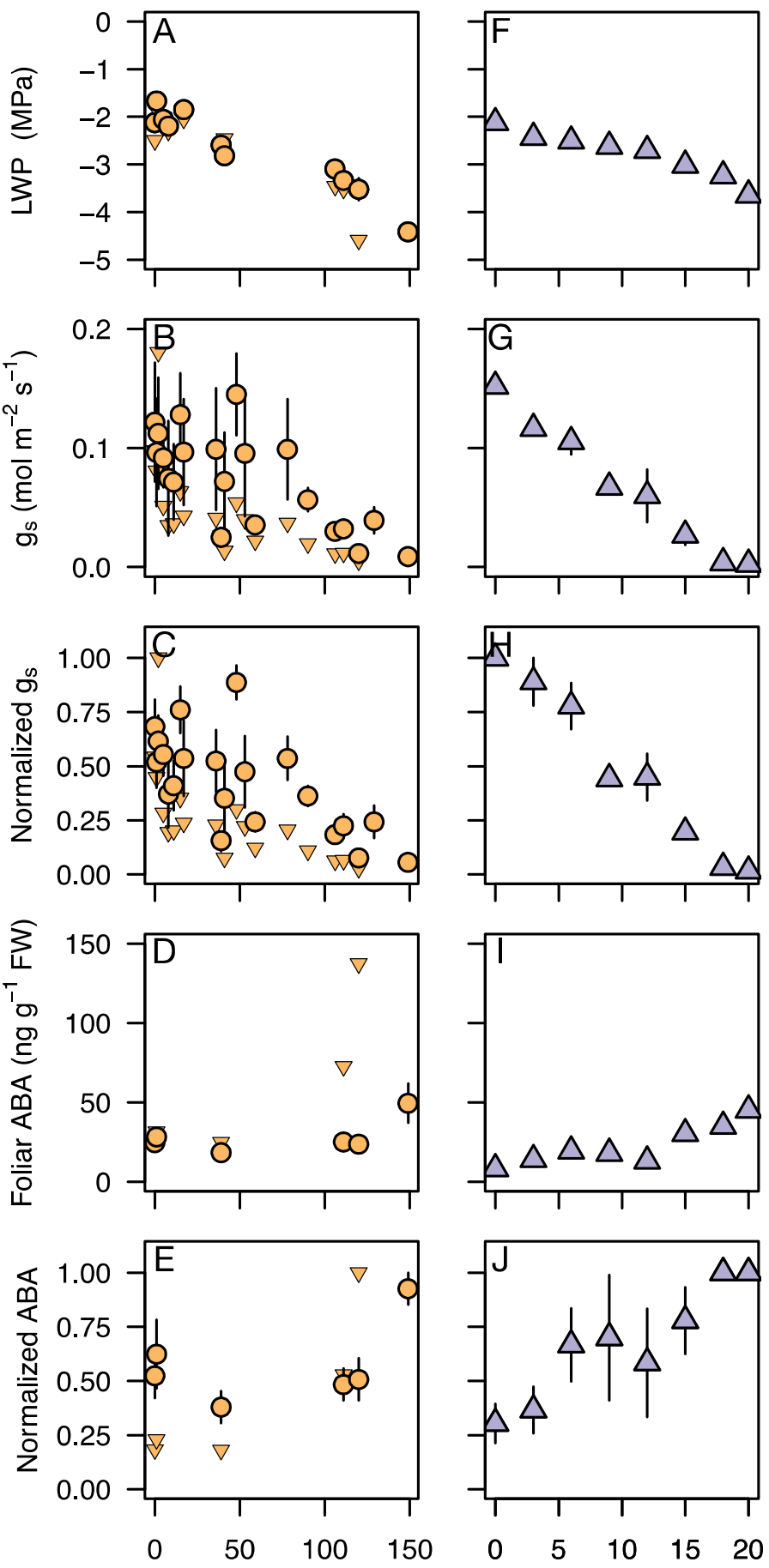

Day of experiment

Day of experiment

Figure 2. Changes in leaf water potential $(\mathrm{LWP})(\mathbf{A}, \mathbf{F})$, stomatal conductance $g_{s}(\mathbf{B}, \mathbf{G}), g_{s}$ normalized by the individual-specific maximum $(\mathbf{C}, \mathbf{H})$, foliar ABA levels $(\mathbf{D}, \mathbf{I})$, and foliar ABA concentration normalized by its individual-specific maximum $(\mathbf{E}, \mathbf{J})$ during the drought experiment for Avicennia marina (orange circles; inverted triangles represent one individual that died before the last measurement) and Bruguiera gymnorrhiza (purple triangles). Note the different durations of drought for the two species. Points represent means \pm SE for individuals of each species measured on each day. Means for A. marina do not include the one individual that died prior to the end of the experiment. 

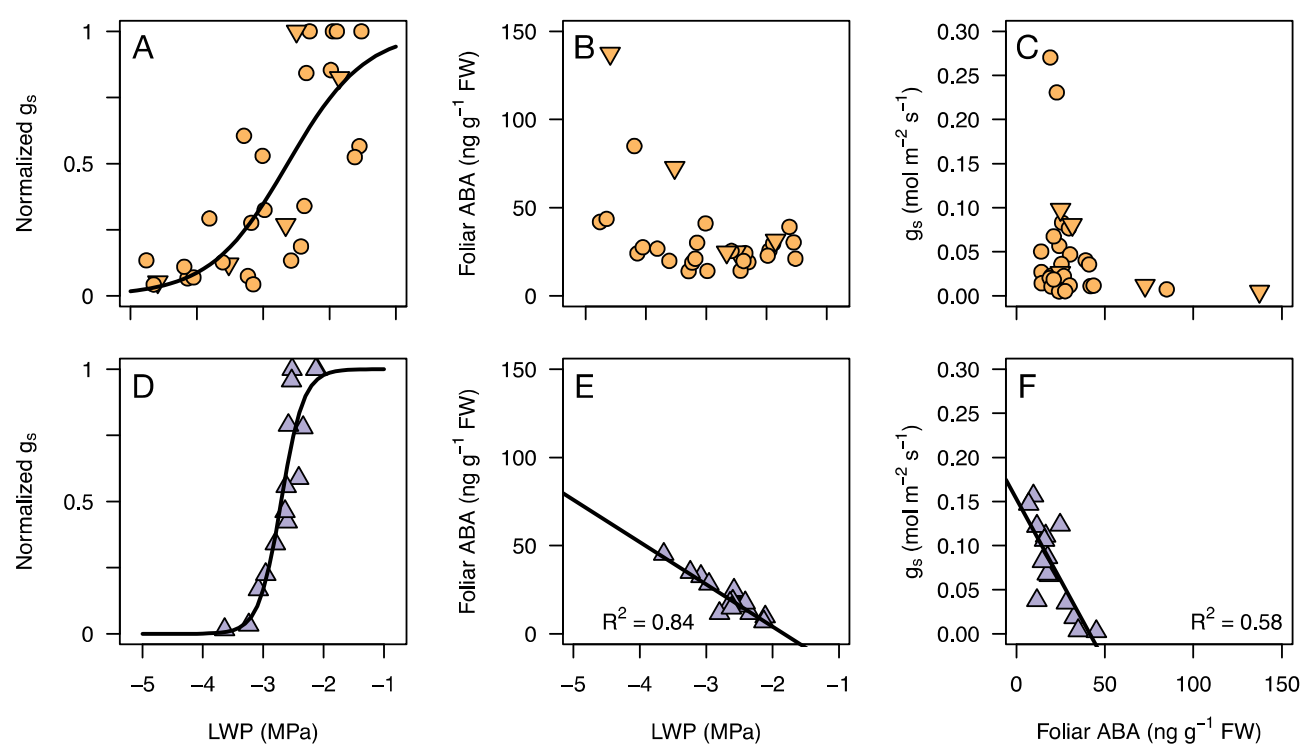

Figure 3. Relationships between leaf water potential (LWP) and stomatal conductance $\left(g_{s}\right)$ normalized by the individual plant-specific maximum (A,D) during the drought experiment, between LWP and foliar ABA (B,E), and between foliar $\mathrm{ABA}$ and $g_{s}(\mathbf{C}, \mathbf{F})$ of Avicennia marina (A-C; inverted triangles for an individual that died before the last measurement) and Bruguiera gymnorrhiza (D-F). Lines represent significant linear or nonlinear regressions.

\subsection{Hydraulic Safety Margins}

A. marina seedlings had a $\mathrm{P}_{\mathrm{g} 12}-\mathrm{P}_{50}$ of $3.75 \mathrm{MPa}$, and B. gymnorrhiza seedlings had 1.05 MPa. A. marina adults had a $\mathrm{P}_{\mathrm{g} 12}-\mathrm{P}_{50}$ of $4.50 \mathrm{MPa}$, and B. gymnorrhiza adults had $0.25 \mathrm{MPa}$ (Table 2). Combining $g_{s}$ responses to declining LWP with embolism vulnerability facilitated calculating the water potential safety margin between stomatal closure and incipient stem cavitation $\left(\mathrm{P}_{\mathrm{g} 12}-\mathrm{P}_{12}\right)$. Stomatal closure in A. marina occurred substantially before embolism spread, with initial stomatal closure (i.e., $g_{s}$ at $88 \%$ of maximum; $\mathrm{P}_{\text {g88 }}$ ) occurring at $-1.47 \mathrm{MPa}$ and complete stomatal closure $\left(\mathrm{P}_{\mathrm{g} 12}\right)$ occurring at $-3.80 \mathrm{MPa}$, while incipient embolism $\left(\mathrm{P}_{12}\right)$ occurred at $-5.71 \pm 0.48 \mathrm{MPa}$ for adults and $-5.39 \pm 0.44 \mathrm{MPa}$ for seedlings (Table 2). Thus, stomatal closure occurred approximately 1.91 MPa higher (less negative) than incipient embolism formation $\left(\mathrm{P}_{12}\right)$ in adults and 1.59 MPa higher (less negative) in seedlings of $A$. marina. In contrast, B. gymnorrhiza exhibited no such safety margin between stomatal closure and stem embolism spread. Stomatal closure in B. gymnorrhiza began $\left(\mathrm{P}_{\mathrm{g} 88}\right)$ at $-2.33 \mathrm{MPa}$ and was completely closed $\left(\mathrm{P}_{\mathrm{g} 12}\right)$ at $-3.08 \mathrm{MPa}$, while $\mathrm{P}_{12}$ for adults occurred at $-2.56 \mathrm{MPa}$ and $\mathrm{P}_{88}$ occurred at $-3.02 \mathrm{MPa}$. B. gymnorrhiza seedlings were more vulnerable to embolism than $A$. marina seedlings, with incipient embolism $\left(\mathrm{P}_{12}\right)$ occurring at $-3.60 \mathrm{MPa}$ and nearly complete embolism $\left(\mathrm{P}_{88}\right)$ occurring at $-4.53 \mathrm{MPa}$. Thus, B. gymnorrhiza seedlings exhibited a small safety margin (0.52 $\mathrm{MPa})$ between $\mathrm{P}_{\mathrm{g} 12}$ and $\mathrm{P}_{12}$.

\section{Discussion}

Our results showed contrasting water use patterns, stomatal regulation, and drought responses of two co-occurring mangrove species. The difference in water use pattern and stomatal regulation is closely related to the strategy to resist drought-induced xylem embolism. While A. marina mainly relies on embolism resistance in drought response, B. gymnorrhiza relies on sensitive stomatal control. Consistent with high embolism resistance, $A$. marina showed more aggressive water use under well-watered conditions indicated by significantly higher transpiration and photosynthesis compared to B. gymnorrhiza. The difference could also be related to their salt management strategies. Because B. gymnorrhiza excludes salt from its roots more efficiently than A. marina [49,77-79], it may also require larger water potential gradients to extract water from seawater. A need for 
low water potentials, but low embolism resistance and narrow hydraulic safety margin in B. gymnorrhiza may require stomata to be highly sensitive, thus relying on an ABA-related active response. Our results highlight mechanisms that underlie variation in drought responses among mangrove species, shedding light on recent, widespread mangrove mortality during drought $[63,64]$.

\subsection{Stomatal Regulation during Drought}

Limiting water loss through stomatal closure is an important physiological response to physiological drought. Although the water potentials at which $g_{s}$ declined were similar in both species (-2.63 vs. $-2.70 \mathrm{MPa}$ in $\left.\mathrm{P}_{\mathrm{g} 50}\right), g_{s}$ in $B$. gymnorrhiza was much more sensitive to declining LWP than in A. marina (Figure 3). In B. gymnorrhiza, $g_{s}$ operated over an extremely narrow range of LWP, with $12 \%$ and $88 \%$ stomatal closure occurring over only $0.75 \mathrm{MPa}$ (Figure 3D). Meanwhile, $g_{s}$ in $A$. marina functioned over a wider range of water potentials, which agree with its greater salt tolerance. This stomatal sensitivity could be further compared to the stomatal responses to changes in VPD [42,49,80].

The two mangrove species showed distinct differences in their responsiveness to ABA during drought, while their ABA concentrations were significantly lower when compared with other angiosperm and gymnosperm species [35]. When B. gymnorrhiza leaves accumulated ABA as the drought treatment proceeded with the decline in LWP, A. marina leaves exhibited no change, even though the foliar ABA concentrations were in a similar range for the two species (Figures 2 and 3). Similarly, $g_{s}$ was linearly related to foliar ABA concentration in B. gymnorrhiza, but not in $A$. marina, as foliar ABA concentration in $A$. marina did not begin to increase until leaves wilted or just before leaf senescence, which did not occur until months withholding water. The longevity of $A$. marina leaves during water stress may be linked to the delayed onset of ABA upregulation, consistent with results showing delayed leaf senescence in mutants with impaired ABA signaling [81]. The hormonal regulation of stomatal conductance needs further validation in mangrove species due to interspecific variation in stomatal sensitivity to ABA and water stress, as our results suggest that there may be large differences in ABA dynamics among mangrove species. ABA levels are known to be unusually low in mangrove reproductive structures, associated with vivipary [60], but similar levels of foliar ABA in A. marina and B. gymnorrhiza suggest that ABA concentration alone is not indicative of the physiological responsiveness.

\subsection{Vulnerability to Embolism}

The two mangrove species also differed substantially in the vulnerability to xylem embolism spread. A. marina appeared to be much more resistant to embolism, with incipient embolism in seedlings $\left(\mathrm{P}_{12}\right)$ not occurring until $-5.39 \pm 0.44 \mathrm{MPa}$, a water potential at which B. gymnorrhiza seedlings $\left(\mathrm{P}_{88}=-4.53 \pm 0.35 \mathrm{MPa}\right)$ and adults $\left(\mathrm{P}_{88}=-3.02 \pm 0.07 \mathrm{MPa}\right)$ were completely embolized (Figure 1). greater resistance to embolism in $A$. marina may be associated with its need to tolerate low water potentials, as it takes up and transports saline water, altering stem hydraulic properties, and eventually secretes salt out of its leaves [82]. B. gymnorrhiza, on the other hand, avoids low water potentials and has a much more vulnerable xylem, with incipient embolism occurring at $-2.56 \pm 0.15 \mathrm{MPa}$ in adults and $-3.60 \pm 0.32 \mathrm{MPa}$ in seedlings (Table 2; Figure 1). A. marina had a $\mathrm{P}_{50}$ comparable to the most resistant angiosperms measured previously [4], and together, these two species studied here spanned almost the full range of $\mathrm{P}_{50}$ reported for other mangrove species $[13,43,44,47,48]$. Surprisingly, how detrimental stem embolism is to the hydraulic pathway remains poorly known; even though embolism is thought to be irreversible without positive pressures, stems can experience substantial loss of conductivity without a similar decline in hydraulic conductance and increase in mortality rate $[15,30,83]$.

While these interspecific differences are associated with differences in salt management strategy, other factors are also likely to influence the physiology of these species during drought. For example, A. marina shows greater xylem cavitation resistance, which may be due to xylem plasticity because mangrove vessels can become narrower as salinity 
increases $[13,84]$. Similarly, mangroves are thought to have traits associated with high embolism resistance, such as higher vessel density, higher vessel grouping index [85], smaller vessel diameter, and successive and simultaneous cambia [86], all of which may be plastic (e.g., vary in response to salinity) and could change ontogenetically. However, we found little evidence for plasticity in $\mathrm{P}_{50}$, based on comparisons of seedlings and adults, in either species (Table 2), although seedlings and adults of each species came from different populations. Additionally, there was a significant difference between species in stomatal response to declining LWP, but this difference was not as large as the difference in embolism resistance. If the recent, widespread mangrove mortality following drought was due, in part, to drought-induced hydraulic failure, then drought may also be an important factor shaping mangrove xylem anatomy and physiology.

Notably, the vulnerability values reported here using the optical vulnerability method seem to be different from those previously reported based on air-injection and bench dehydration methods [13] for B. gymnorrhiza. $\mathrm{P}_{50}$ was previously reported to be $-8.32 \mathrm{MPa}$ for B. gymnorrhiza compared to $-2.83 \mathrm{MPa}$ in this study. Protocols for the cavitron [87], bench-drying [88], and air-injection methods [89,90] typically involve flushing excised stems with fresh water to remove air bubbles in order to measure maximum conductivity. However, flushing refills xylem conduits that were otherwise nonfunctional in the intact plant and can introduce bubble nuclei, which can produce erroneous vulnerability curves [91]. These differences in measured vulnerability likely reflect differences between the methods in sample preparation. Although the optical method has largely agreed with other methods [70,92-95], it has not previously been applied and studied in mangroves.

The discrepancy between OV and other methods is presumably caused by nonxylem tissues (fibers or parenchyma) dehydration or damage to fibers adjacent to the cambium in the debarked area [96,97]. In our study, cavitation resistance was much lower from the OV method than the bench dehydration/hydraulic method in B. gymnorrhiza. The damage to fibers or xylem during the debarking process at the beginning of the process would cause lower cavitation resistance (i.e., more vulnerable to embolism) [96]. On the other hand, flushing stems may cause lower $\mathrm{P}_{50}$ using the bench dehydration/hydraulic measurement method as reported previously [13]. Further methods comparisons on mangrove species could provide more information about the differences in vulnerability reported here.

\subsection{Hydraulic Safety Margins Associated with Different Salt Management Strategies}

Calculation of the safety margin between stomatal closure $\left(\mathrm{P}_{\mathrm{g} 12}\right)$ and incipient embolism formation $\left(\mathrm{P}_{12}\right)$ reiterated the different hydraulic strategies of the two species: A. marina seedlings had a safety margin of $1.59 \mathrm{MPa}$, while B. gymnorrhiza seedlings had a narrower safety margin of $0.52 \mathrm{MPa}$. This narrow safety margin in B. gymnorrhiza seedlings suggests that stem xylem may have embolized soon after complete stomatal closure. However, for water to move through the soil-plant-atmosphere continuum, leaf water potentials must be lower than stem water potentials, and the magnitude of this difference may be relatively constant across species, approximately $-0.32 \mathrm{MPa}$ [98]. Therefore, even with zero safety margin calculated as $\mathrm{P}_{\mathrm{g} 12}-\mathrm{P}_{12}$, stomata may close temporally before incipient stem embolism, effectively acting as a hydraulic fuse [99-101]. Knowing whether leaves are more vulnerable to embolism than stems would help to clarify the sequence of physiological responses to declining water potential throughout the plant and the range of water potentials over which these physiological responses occur.

Although A. marina and B. gymnorrhiza are widely distributed species that often cooccur $[45,51,66]$, only A. marina can be found in extremely saline conditions. For example, it is found in the northern Red Sea, where the seawater is hypersaline (salinity of $0.70 \mathrm{M}$ salt) and the atmosphere is extremely hot and dry $[78,102]$. Such conditions are usually accompanied by high transpiration rates during which the shoots could uptake large quantities of salt from the seawater [45]. Uptake of salt from the seawater and secretion from the shoots requires tolerance of low water potentials, which are evident in A. marina. Extreme xylem resistance to cavitation (Figure 1), leaf hydraulic recovery by harvesting water from 
atmospheres through deliquescence of salt [103] and shoot surface water uptake [104], and increased salt secretion during drought [58] may also help to explain why A. marina is able to grow across such a wide range of environmental conditions. However, recent drought and high temperature have nonetheless led to substantial mortality of A. marina [64]. In contrast, B. gymnorrhiza typically occurs in habitats that receive periodic freshwater [45], which could help maintain its water potential within its narrow physiological tolerance allowing it to generate a high water potential gradient required to filter water from seawater. The interspecific differences in drought responses suggest that drought physiology could be an additional axis of differentiation among mangrove species that can likely influence their ecological tolerances and niche occupation.

\section{Conclusions}

In conclusion, we found contrasting patterns in photosynthetic gas exchange, stomatal and embolism thresholds, and drought resistance strategies between two mangrove species. $A$. marina adopts a drought tolerance strategy with high cavitation resistance and leaf tolerance to low water potentials. In contrast, B. gymnorrhiza uses a more avoidant strategy with sensitive stomatal control associated with ABA regulation and early leaf wilting to protect vulnerable xylem. Near-constant access to saline water alone is insufficient to support mangrove plants, and other aspects of physiology besides salt management strategy may be important in understanding mangrove responses to climate change. The ability of A. marina to maintain water transport and photosynthetic gas exchange during periods of lower water potential could be beneficial for it to maintain positive carbon assimilation under drought conditions and may also explain its distribution in areas with extremely saline and dry conditions. However, substantial mortality of $A$. marina during recent drought and heat incidents [64] suggests that the increase in extreme weather conditions due to climate change may have pushed it over the brink of hydraulic failure. In addition to sea-level rise, which is threatening the survival of mangroves [61,62], drought and high temperatures may also threaten mangroves. Conserving mangroves and predicting their responses to climate change will require physiological research that elucidates the thresholds of drought-induced damage in different organs and the mechanisms that underlie drought-induced mortality for more species.

Supplementary Materials: The following are available online at https:/ /www.mdpi.com/article/10 $.3390 / w 13141945 / s 1$, Figure S1: Time course of volumetric water content. Figure S2: The relationship between stomatal conductance $\left(g_{s}\right)$ and leaf water potential (LWP) during the drought experiment.

Author Contributions: Conceptualization, G.-F.J., T.J.B., and K.-F.C.; Formal analysis, G.-F.J. and A.B.R.; Funding acquisition, G.-F.J. and K.-F.C.; Investigation, G.-F.J., J.-Y.L., and H.-T.S.; Methodology, G.-F.J. and T.J.B.; Writing—original draft, G.-FJ.; Writing—review and editing, G.-F.J., A.B.R., P.P., Y.-J.Z., and T.J.B. All authors have read and agreed to the published version of the manuscript.

Funding: This work was supported by the research grants of Natural Science Foundation of China (31860195) and Natural Science Foundation of guangxi Province of China (Grant Nos. 2014GXNSFBA118075 and 2015GXNSFAA139085) to g.-F.J., Foundation of guangxi "BaGui Scholar" (C33600992001) and Natural Science Foundation of China (31670406) to K.-F.C., and a visiting fellowship of guangxi Department for Foreign Experts (GX2018019) to support T.J.B. and A.B.R.

Informed Consent Statement: Not applicable.

Data Availability Statement: Please refer to Section 2 in this article for the sources of the publicly archived data used in this study.

Acknowledgments: We thank Alison Wee for providing seedlings and Megan K. Bartlett for useful comments. We thank Guangxi Beilun Estuary National Nature Reserve for helping in the field.

Conflicts of Interest: The authors declare no conflict of interest. 


\section{References}

1. Brodribb, T.J.; Powers, J.; Cochard, H.; Choat, B. hanging by a thread? Forests and drought. Science 2020, 368, 261-266. [CrossRef]

2. Brodribb, T.; Cochard, h.; Rodriguez Dominguez, C. Measuring the pulse of trees; using the vascular system to predict tree mortality in the 21st century. Conserv. Physiol. 2019, 7, coz046. [CrossRef]

3. Engelbrecht, B.M. Plant ecology: Forests on the brink. Nature 2012, 491, 675-677. [CrossRef] [PubMed]

4. Choat, B.; Jansen, S.; Brodribb, T.J.; Cochard, H.; Delzon, S.; Bhaskar, R.; Bucci, S.J.; Feild, T.S.; gleason, S.M.; hacke, U.G.; et al. global convergence in the vulnerability of forests to drought. Nature 2012, 491, 752-755. [CrossRef] [PubMed]

5. Allen, C.D.; Macalady, A.K.; Chenchouni, H.; Bachelet, D.; McDowell, N.; Vennetier, M.; Kitzberger, T.; Rigling, A.; Breshears, D.D.; hogg, E.T. A global overview of drought and heat-induced tree mortality reveals emerging climate change risks for forests. For. Ecol. Manag. 2010, 259, 660-684. [CrossRef]

6. Adams, H.D.; Macalady, A.K.; Breshears, D.D.; Allen, C.D.; Stephenson, N.L.; Saleska, S.R.; huxman, T.E.; McDowell, N.G. Climate-induced tree mortality: Earth system consequences. Eos Trans. Am. Geophys. Union 2010, 91, 153-154. [CrossRef]

7. Simonin, K.A.; Roddy, A.B. genome downsizing, physiological novelty, and the global dominance of flowering plants. PloS Biol. 2018, 16, e2003706. [CrossRef]

8. Brodribb, T.J.; McAdam, S.A.M. Evolution of the stomatal regulation of plant water content. Plant Physiol 2017, 174, 639-649. [CrossRef]

9. Sack, L.; holbrook, N.M. Leaf hydraulics. Annu. Rev. Plant Biol. 2006, 57, 361-381. [CrossRef]

10. Sperry, J.; Pockman, W. Limitation of transpiration by hydraulic conductance and xylem cavitation in betula occidentalis. Plant Cell Environ. 1993, 16, 279-287. [CrossRef]

11. Jones, H.; Sutherland, R. Stomatal control of xylem embolism. Plant Cell Environ. 1991, 14, 607-612. [CrossRef]

12. Meinzer, F.; Grantz, D. Stomatal and hydraulic conductance in growing sugarcane: Stomatal adjustment to water transport capacity. Plant Cell Environ. 1990, 13, 383-388. [CrossRef]

13. Jiang, G.F.; goodale, U.M.; Liu, Y.Y.; Hao, G.Y.; Cao, K.F. Salt management strategy defines the stem and leaf hydraulic characteristics of six mangrove tree species. Tree Physiol. 2017, 37, 389-401. [CrossRef] [PubMed]

14. Hao, G.-Y.; Jones, T.J.; Luton, C.; Zhang, Y.-J.; Manzane, E.; Scholz, F.G.; Bucci, S.J.; Cao, K.-F.; Goldstein, G. hydraulic redistribution in dwarf rhizophora mangle trees driven by interstitial soil water salinity gradients: Impacts on hydraulic architecture and gas exchange. Tree Physiol. 2009, 29, 697-705. [CrossRef]

15. Brodersen, C.R.; Roddy, A.B.; Wason, J.W.; McElrone, A.J. Functional status of xylem through time. Annu. Rev. Plant Biol. 2019, 70, 407-433. [CrossRef] [PubMed]

16. Tyree, M.T.; Sperry, J.S. Vulnerability of xylem cavitation and embolism. Annu. Rev. Plant Physiol. Plant Mol. Biol. 1989, 40, 19-38. [CrossRef]

17. Sperry, J.S.; Tyree, M.T. Mechanism of water stress-induced xylem embolism. Plant Physiol. 1988, 88, 581-587. [CrossRef]

18. Adams, H.D.; Zeppel, M.J.B.; Anderegg, W.R.L.; Hartmann, H.; Landhausser, S.M.; Tissue, D.T.; Huxman, T.E.; Hudson, P.J.; Franz, T.E.; Allen, C.D.; et al. A multi-species synthesis of physiological mechanisms in drought-induced tree mortality. Nat. Ecol. Evol. 2017, 1, 1285-1291. [CrossRef] [PubMed]

19. Brodribb, T.J.; Cochard, H. hydraulic failure defines the recovery and point of death in water-stressed conifers. Plant Physiol. 2009, 149, 575-584. [CrossRef]

20. Lens, F.; Tixier, A.; Cochard, H.; Sperry, J.S.; Jansen, S.; herbette, S. Embolism resistance as a key mechanism to understand adaptive plant strategies. Curr. Opin. Plant Biol. 2013, 16, 287-292. [CrossRef]

21. Choat, B.; Sack, L.; holbrook, N.M. Diversity of hydraulic traits in nine cordia species growing in tropical forests with contrasting precipitation. New Phytol. 2007, 175, 686-698. [CrossRef]

22. Brodribb, T.J.; McAdam, S.A.; Jordan, G.J.; Martins, S.C. Conifer species adapt to low-rainfall climates by following one of two divergent pathways. Proc. Natl. Acad. Sci. USA 2014, 111, 14489-14493. [CrossRef] [PubMed]

23. Vinya, R.; Malhi, Y.; Fisher, J.B.; Brown, N.; Brodribb, T.J.; Aragao, L.E. Xylem cavitation vulnerability influences tree species' habitat preferences in miombo woodlands. Oecologia 2013, 173, 711-720. [CrossRef]

24. Oliveira, R.S. Can hydraulic traits be used to predict sensitivity of drought-prone forests to crown decline and tree mortality? Plant Soil 2013, 364, 1-3. [CrossRef]

25. Pockman, W.T.; Sperry, J.S. Vulnerability to xylem cavitation and the distribution of sonoran desert vegetation. Am. J. Bot. 2000, 87, 1287-1299. [CrossRef]

26. Brodribb, T.; Hill, R.S. The importance of xylem constraints in the distribution of conifer species. New Phytol. 1999, 143, 365-372. [CrossRef]

27. Tyree, M.T.; Davis, S.D.; Cochard, H. Biophysical perspectives of xylem evolution: Is there a tradeoff of hydraulic effichîncy for vulnerability to dysfunction? IAWA J. 1994, 15, 335-360. [CrossRef]

28. Brodribb, T.J.; Buckley, T.N. Leaf water transport: A core system in the evolution and physiology of photosynthesis. In The Leaf: A Platform for Performing Photosynthesis, Advances in Photosynthesis and Respiration; Adams, W.W., III, Terashima, I., Eds.; Springer International Publishing AG: Berlin/Heidelberg, Germany, 2018; pp. 81-92.

29. Anderegg, W.; Wolf, A.; Arangovelez, A.; Choat, B.; Chmura, D.J.; Jansen, S.; Kolb, T.; Li, S.; Meinzer, F.C.; Pita, P. Woody plants optimise stomatal behaviour relative to hydraulic risk. Ecol. Lett. 2018, 21, 968-977. [CrossRef] [PubMed] 
30. Meinzer, F.C. Co-ordination of vapour and liquid phase water transport properties in plants. Plant Cell Environ. 2002, 25, 265-274. [CrossRef] [PubMed]

31. Zuccarini, P.; Ciurli, A.; Alpi, A.; Hegedüšová, K. hydraulic and chemical mechanisms in the response of pinus pinaster ait. To conditions of water stress. Ekol. Bratisl. 2011, 30, 422-437.

32. Mittelheuser, C.J.; van Stevenick, R.F.M. Stomatal closure and the inhibition of transpiration by (rs)-abscisic acid. Nature 1969, 221, 281-282. [CrossRef]

33. Franks, P.J.; Berry, J.A.; Lombardozzi, D.L.; Bonan, G.B. Stomatal function across temporal and spatial scales: Deep-time trends, land-atmosphere coupling and global models. Plant Physiol. 2017, 174, 583-602. [CrossRef]

34. Santelia, D.; Lawson, T. Rethinking guard cell metabolism. Plant Physiol. 2016, 172, 1371-1392. [CrossRef]

35. Brodribb, T.J.; McAdam, S.A. Passive origins of stomatal control in vascular plants. Science 2011, 331, 582-585. [CrossRef]

36. Martin-StPaul, N.; Delzon, S.; Cochard, h. Plant resistance to drought depends on timely stomatal closure. Ecol. Lett. 2017, 20, 1437-1447. [CrossRef] [PubMed]

37. Powers, J.S.; Vargas-G, G.; Brodribb, T.J.; Schwartz, N.B.; Perez-Aviles, D.; Smith-Martin, C.M.; Becknell, J.M.; Aureli, F.; Blanco, R.; Calderón-Morales, E.; et al. A catastrophic tropical drought kills hydraulically vulnerable tree species. Glob. Chang. Biol. 2020, 26, 3122-3133. [CrossRef]

38. Creek, D.; Lamarque, L.J.; Torres-Ruiz, J.M.; Parise, C.; Burlett, R.; Tissue, D.T.; Delzon, S. Xylem embolism in leaves does not occur with open stomata: Evidence from direct observations using the optical visualization technique. J. Exp. Bot. 2020, 71, 1151-1159. [CrossRef] [PubMed]

39. Ziegler, C.; Coste, S.; Stahl, C.; Delzon, S.; Levionnois, S.; Cazal, J.; Cochard, H.; Esquivel-Muelbert, A.; Goret, J.-Y.; Heuret, P. Large hydraulic safety margins protect neotropical canopy rainforest tree species against hydraulic failure during drought. Ann. For. Sci. 2019, 76, 115. [CrossRef]

40. Choat, B.; Brodribb, T.J.; Brodersen, C.R.; Duursma, R.A.; López, R.; Medlyn, B.E. Triggers of tree mortality under drought. Nature 2018, 558, 531-539. [CrossRef]

41. Benito Garzón, M.; González Muñoz, N.; Wigneron, J.P.; Moisy, C.; Fernández-Manjarrés, J.; Delzon, S. The legacy of water deficit on populations having experienced negative hydraulic safety margin. Glob. Ecol. Biogeogr. 2018, 27, 346-356. [CrossRef]

42. Skelton, R.P.; West, A.G.; Dawson, T.E. Predicting plant vulnerability to drought in biodiverse regions using functional traits. Proc. Natl. Acad. Sci. USA 2015, 112, 5744-5749. [CrossRef] [PubMed]

43. Jiang, X.; Choat, B.; Zhang, Y.-J.; Guan, X.-Y.; Shi, W.; Cao, K.-F. Variation in xylem hydraulic structure and function of two mangrove species across a latitudinal gradient in eastern australia. Water 2021, 13, 850. [CrossRef]

44. Sperry, J.S.; Tyree, M.T.; Donnelly, J.R. Vulnerability of xylem to embolism in a mangrove vs an inland species of rhizophoraceae. Physiol. Plant. 1988, 74, 276-283. [CrossRef]

45. Ball, M.C. Ecophysiology of mangroves. Trees 1988, 2, 129-142. [CrossRef]

46. Scholander, P.F.; Hammel, H.T.; Hemmingsen, E.A.; Bradstreet, E.D. hydrostatic pressure and osmotic potential in leaves of mangroves and some other plants. Proc. Natl. Acad. Sci. USA 1964, 52, 119-125. [CrossRef]

47. Ewers, F.W.; Lopez-Portillo, J.; Angeles, g.; Fisher, J.B. hydraulic conductivity and embolism in the mangrove tree laguncularia racemosa. Tree Physiol. 2004, 24, 1057-1062. [CrossRef]

48. Melcher, P.J.; Goldstein, G.; Meinzer, F.C.; Yount, D.E.; Jones, T.J.; Holbrook, N.M.; Huang, C. Water relations of coastal and estuarine rhizophora mangle: Xylem pressure potential and dynamics of embolism formation and repair. Oecologia 2001, 126, 182-192. [CrossRef]

49. Reef, R.; Lovelock, C.E. Regulation of water balance in mangroves. Ann. Bot. 2015, 115, 385-395. [CrossRef]

50. Krauss, K.W.; Lovelock, C.E.; Mckee, K.L.; Lopez-Hoffman, L.; Ewe, S.M.L.; Sousa, W.P. Environmental drivers in mangrove establishment and early development: A review. Aquat. Bot. 2008, 89, 105-127. [CrossRef]

51. Duke, N.C. Mangrove floristics and biogeography. In Tropical Mangrove Ecosystems; Robertson, A.I., Alongi, D.M., Eds.; American geophysiocal Union: Washington, DC, USA, 1992; Volume 41, pp. 63-100.

52. Nguyen, H.T.; Meir, P.; Sack, L.; Evans, J.R.; Oliveira, R.S.; Ball, M.C. Leaf water storage increases with salinity and aridity in the mangrove avicennia marina: Integration of leaf structure, osmotic adjustment, and access to multiple water sources. Plant Cell Environ. 2017, 40, 1576-1591. [CrossRef]

53. Nguyen, H.T.; Meir, P.; Wolfe, J.; Mencuccini, M.; Ball, M.C. Plumbing the depths: Extracellular water storage in specialized leaf structures and its functional expression in a three-domain pressure-volume relationship. Plant Cell Environ. 2016, 40, 1021-1038. [CrossRef]

54. Madrid, E.N.; Armitage, A.R.; Lopez-Portillo, J. Avicennia germinans (black mangrove) vessel architecture is linked to chilling and salinity tolerance in the gulf of mexico. Front. Plant Sci. 2014, 5, 503. [CrossRef] [PubMed]

55. Schmitz, N.; Egerton, J.; Lovelock, C.; Ball, M. Light-dependent maintenance of hydraulic function in mangrove branches: Do xylary chloroplasts play a role in embolism repair? New Phytol. 2012, 195, 40-46. [CrossRef] [PubMed]

56. Cardona-Olarte, P.; Krauss, K.W.; Twilley, R.R. Leaf gas exchange and nutrient use efficiency help explain the distribution of two neotropical mangroves under contrasting flooding and salinity. Int. J. For. Res. 2013, 2013, 524-625. [CrossRef]

57. Lovelock, C.E.; Ball, M.C.; Choat, B.; Engelbrecht, B.M.; holbrook, N.M.; Feller, I.C. Linking physiological processes with mangrove forest structure: Phosphorus deficiency limits canopy development, hydraulic conductivity and photosynthetic carbon gain in dwarf rhizophora mangle. Plant Cell Environ. 2006, 29, 793-802. [CrossRef] 
58. Sobrado, M. Effect of drought on leaf gland secretion of the mangrove avicennia germinans L. Trees 2002, 16, 1-4. [CrossRef]

59. Sobrado, M. Effect of high external nacl concentration on the osmolality of xylem sap, leaf tissue and leaf glands secretion of the mangrove avicennia germinans (1.) L. Flora 2001, 196, 63-70. [CrossRef]

60. Farnsworth, E.J.; Farrant, J.M. Reductions in abscisic acid are linked with viviparous reproduction in mangroves. Am. J. Bot. 1998, 85, 760-769. [CrossRef] [PubMed]

61. Saintilan, N.; Khan, N.S.; Ashe, E.; Kelleway, J.J.; Rogers, K.; Woodroffe, C.D.; Horton, B.P. Thresholds of mangrove survival under rapid sea level rise. Science 2020, 368, 1118-1121. [CrossRef] [PubMed]

62. Lovelock, C.E. Blue carbon from the past forecasts the future. Science 2020, 368, 1050-1052. [CrossRef]

63. Mafigholami, D.; Mahmoudi, B.; Zenner, E.K. An analysis of the relationship between drought events and mangrove changes along the northern coasts of the persian gulf and oman sea. Estuar. Coast. Shelf Sci. 2017, 199, 141-151. [CrossRef]

64. Duke, N.C.; Kovacs, J.M.; Griffiths, A.D.; Preece, L.; Hill, D.J.E.; Oosterzee, P.V.; Mackenzie, J.; Morning, H.S.; Burrows, D. Large-scale dieback of mangroves in australia's gulf of carpentaria: A severe ecosystem response, coincidental with an unusually extreme weather event. Mar. Freshw. Res. 2017, 68, 1816-1829. [CrossRef]

65. Matthijs, S.; Tack, J.; Speybroeck, D.V.; Koedam, N. Mangrove species zonation and soil redox state, sulphide concentration and salinity in gazi bay (kenya), a preliminary study. Mangroves Salt Marshes 1999, 3, 243-249. [CrossRef]

66. Clough, B.F. Primary productivity and growth of mangrove forests. In Tropical Mangrove Ecosystems; Robertson, A.I., Alongi, D.M., Eds.; American geophysical Union: Washington, DC, USA, 1992; Volume 41, pp. 225-249.

67. Tomlinson, P.B. The Botany of Mangroves; Cambridge University Press: Cambridge, UK; New York, NY, USA, 1986; p. xii. 413p.

68. Odum, W.E.; McIvor, C.C.; Smith III, T.J. The Ecology of the Mangroves of South Florida: A Community Profile; DTIC Document 5137473; DTIC: Charlottesville, VA, USA, 1982.

69. Scholander, P.; hammel, H.; hemmingsen, E.; Garey, W. Salt balance in mangroves. Plant Physiol. 1962, 37, 722. [CrossRef] [PubMed]

70. Brodribb, T.J.; Carriqui, M.; Delzon, S.; Lucani, C. Optical measurement of stem xylem vulnerability. Plant Physiol. 2017, 174, 2054-2061. [CrossRef] [PubMed]

71. Brodribb, T.J.; Bienaime, D.; Marmottant, P. Revealing catastrophic failure of leaf networks under stress. Proc. Natl. Acad. Sci. USA 2016, 113, 4865-4869. [CrossRef] [PubMed]

72. Schindelin, J.; Arganda-Carreras, I.; Frise, E.; Kaynig, V.; Longair, M.; Pietzsch, T.; Preibisch, S.; Rueden, C.; Saalfeld, S.; Schmid, B. Fiji: An open-source platform for biological-image analysis. Nat. Methods 2012, 9, 676. [CrossRef] [PubMed]

73. McAdam, S. Physicochemical quantification of abscisic acid levels in plant tissues with an added internal standard by ultraperformance liquid chromatography. Bio-Protocol 2015, 5, 1-13. [CrossRef]

74. Vilaró, F.; Canela-Xandri, A.; Canela, R. Quantification of abscisic acid in grapevine leaf (vitis vinifera) by isotope-dilution liquid chromatography-mass spectrometry. Anal. Bioanal. Chem. 2006, 386, 306-312. [CrossRef]

75. Bates, D.; Mächler, M.; Bolker, B.; Walker, S. Fitting linear mixed-effects models using lme4. Stat. Comput. 2015, 067, 133-199.

76. Duursma, R.; Choat, B. Fitplc_-An r package to fit hydraulic vulnerability curves. J. Plant hydraul. 2017, 4, e002. [CrossRef]

77. Paliyavuth, C.; Clough, B.; Patanaponpaiboon, P. Salt uptake and shoot water relations in mangroves. Aquat. Bot. 2004, 78, 349-360. [CrossRef]

78. Waisel, Y.; Eshel, A.; Agami, M. Salt balance of leaves of the mangrove avicennia marina. Physiol. Plant. 1986, 67, 67-72. [CrossRef]

79. Moon, G.J.; Clough, B.F.; Peterson, C.A.; Allaway, W.G. Apoplastic and symplastic pathways in avicennia marina (forsk.) vierh. Roots revealed by fluorescent tracer dyes. Funct. Plant Biol. 1986, 13, 637-648. [CrossRef]

80. Oren, R.; Sperry, J.; Katul, G.; Pataki, D.; Ewers, B.; Phillips, N.; Schäfer, K. Survey and synthesis of intra-and interspecific variation in stomatal sensitivity to vapour pressure deficit. Plant Cell Environ. 1999, 22, 1515-1526. [CrossRef]

81. Zhao, Y.; Chan, Z.; Gao, J.; Xing, L.; Cao, M.; Yu, C.; Hu, Y.; You, J.; Shi, H.; Zhu, Y. Aba receptor pyl9 promotes drought resistance and leaf senescence. Proc. Natl. Acad. Sci. USA 2016, 113, 1949-1954. [CrossRef]

82. López-Portillo, J.; Ewers, F.W.; Angeles, G. Sap salinity effects on xylem conductivity in two mangrove species. Plant Cell Environ. 2005, 28, 1285-1292. [CrossRef]

83. Hammond, W.M.; Yu, K.; Wilson, L.A.; Will, R.E.; Anderegg, W.R.L.; Adams, H.D. Dead or dying? Quantifying the point of no return from hydraulic failure in drought-induced tree mortality. New Phytol. 2019, 223, 1834-1843. [CrossRef] [PubMed]

84. Jantsch, A.; Melo Júnior, J.C.F.D.; Amorim, M.W.; Larcher, L.; Soffiatti, P. Wood anatomy of laguncularia racemosa (combretaceae) in mangrove and transitional forest, southern brazil. Rev. De Biol. Trop. 2018, 66, 647-657. [CrossRef]

85. Robert, E.M.; Koedam, N.; Beeckman, H.; Schmitz, N. A safe hydraulic architecture as wood anatomical explanation for the difference in distribution of the mangroves avicennia and rhizophora. Funct. Ecol. 2009, 23, 649-657. [CrossRef]

86. Schmitz, N.; Robert, E.M.R.; Verheyden, A.; Kairo, J.G.; Beeckman, H.; Koedam, N. A patchy growth via successive and simultaneous cambia: Key to success of the most widespread mangrove species avicennia marina? Ann. Bot. 2008, 101, 49-58. [CrossRef]

87. Cochard, H.; Damour, G.; Bodet, C.; Tharwat, I.; Poirier, M.; Améglio, T. Evaluation of a new centrifuge technique for rapid generation of xylem vulnerability curves. Physiol. Plant. 2005, 124, 410-418. [CrossRef]

88. Sperry, J.S.; Donnelly, J.R.; Tyree, M.T. A method for measuring hydraulic conductivity and embolism in xylem. Plant Cell Environ. 1988, 11, 35-40. [CrossRef] 
89. Wheeler, J.K.; Huggett, B.A.; Tofte, A.N.; Rockwell, F.E.; Holbrook, N.M. Cutting xylem under tension or supersaturated with gas can generate plc and the appearance of rapid recovery from embolism. Plant Cell Environ. 2013, 36, 1938-1949. [CrossRef] [PubMed]

90. Sperry, J.; Saliendra, N. Intra-and inter-plant variation in xylem cavitation in betula occidentalis. Plant Cell Environ. 1994, 17, 1233-1241. [CrossRef]

91. Rockwell, F.E.; Wheeler, J.K.; holbrook, N.M. Cavitation and its discontents: Opportunities for resolving current controversies. Plant Physiol. 2014, 164, 1649-1660. [CrossRef] [PubMed]

92. Chen, Y.J.; Maenpuen, P.; Zhang, Y.J.; Barai, K.; Katabuchi, M.; Gao, H.; Kaewkamol, S.; Tao, L.B.; Zhang, J.L. Quantifying vulnerability to embolism in tropical trees and lianas using five methods: Can discrepancies be explained by xylem structural traits? New Phytol. 2021, 229, 805-819. [CrossRef]

93. Skelton, R.; Diaz, J. Quantifying losses of plant hydraulic function: Seeing the forest, the trees and the xylem. Tree Physiol. 2020, 40, 285-289. [CrossRef]

94. Brodribb, T.; Carriquí, M.; Delzon, S.; McAdam, S.; Holbrook, N. Advanced vascular function discovered in a widespread moss. Nat. Plants 2020, 6, 273-279. [CrossRef]

95. Skelton, R.P.; Brodribb, T.J.; Choat, B. Casting light on xylem vulnerability in an herbaceous species reveals a lack of segmentation. New Phytol. 2017, 214, 561-569. [CrossRef]

96. Venturas, M.D.; Pratt, R.B.; Jacobsen, A.L.; Castro, V.; Fickle, J.C.; Hacke, U.G. Direct comparison of four methods to construct xylem vulnerability curves: Differences among techniques are linked to vessel network characteristics. Plant Cell Environ. 2019, 42, 2422-2436. [CrossRef]

97. Pratt, R.B.; Castro, V.; Fickle, J.C.; Jacobsen, A.L. Embolism resistance of different aged stems of a california oak species (quercus douglasii): Optical and microct methods differ from the benchtop-dehydration standard. Tree Physiol. 2019, 40, 5-18. [CrossRef] [PubMed]

98. Simonin, K.A.; Limm, E.B.; Dawson, T.E. hydraulic conductance of leaves correlates with leaf lifespan: Implications for lifetime carbon gain. New Phytol. 2012, 193, 939-947. [CrossRef] [PubMed]

99. Tyree, M.T.; Zimmermann, M.H. Xylem Structure and the Ascent of Sap; Springer Science \& Business Media: Berlin/Heidelberg, germany, 2013.

100. Tyree, M.T.; Ewers, F.W. The hydraulic architecture of trees and other woody plants. New Phytol. 1991, 119, 345-360. [CrossRef]

101. Zimmermann, M.H. hydraulic architecture of some diffuse-porous trees. Can. J. Bot. 1978, 56, 2286-2295. [CrossRef]

102. Ahmed, E.K.A.; Abdel-Hamid, A. Zonation pattern of avicennia marina and rhizophora mucronata along the red sea coast, egypt. World Appl. Sci. J. 2007, 2, 283-288.

103. Coopman, R.E.; Nguyen, H.T.; Mencuccini, M.; Oliveira, R.S.; Sack, L.; Lovelock, C.E.; Ball, M.C. harvesting water from unsaturated atmospheres: Deliquescence of salt secreted onto leaf surfaces drives reverse sap flow in a dominant arid climate mangrove, avicennia marina. New Phytol. 2021. [CrossRef]

104. Fuenzalida, T.I.; Bryant, C.J.; Ovington, L.I.; Yoon, H.-J.; Oliveira, R.S.; Sack, L.; Ball, M.C. Shoot surface water uptake enables leaf hydraulic recovery in avicennia marina. New Phytol. 2019, 2019, 1504-1511. [CrossRef] [PubMed] 